\section{Les TIC en els processos
d'aprenentatge: Anàlisi de l'ús \\ Les TIC en els processos
d'aprenentatge: Anàlisi de l'ús d'entorns no presencials en seqüències didàctiques reals}

UTE. Revista de Ciències de l'Educació

2016 núm. 2. Pag. 92

ISSN 1135-1438. EISSN 2385-4731

http://revistes.publicacionsurv.cat/index.php/ute

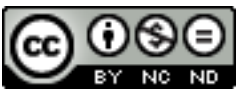

DOI: http://dx.doi.org/10.17345/ute.2016.2.1007

\author{
Marta Badia Soléa \\ Data de defensa: 04/11/2016
}

Paraules clau: Pedagogia, Mètodes pedagògics, tecnología i canvi social.

\title{
Resum
}

La tesi doctoral "Les TIC en els processos d'aprenentatge: Anàlisi de l'ús d'entorns no presencials en seqüències didàctiques reals", analitza i descriu sis itineraris pedagògics dissenyats per tres centres públics d'Educació Secundària a Catalunya.

L'estudi es situa dins del paradigma interpretatiu i utilitza el mètode de l'estudi de cas.

Els sis projectes descrits organitzen els curricula de les matèries implicades de forma globalitzada i concreten com a objectius d'aprenentatge, el desenvolupament de competències.

La investigació s'ha centrat exclusivament en el seguiment i l'observació dels entorns virtuals de cadascun dels tres centres, els quals utilitzen la tecnologia d'una forma habitual, quotidiana i totalment integrada.

L'aproximació teòrica al concepte d'aprenentatge, ens ha permès concretar i actualitzar les característiques del procés d'aprenentatge que fan diferents autors. També ens ha permès identificar el disseny pedagògic com un element determinant per facilitar el desenvolupament real de competències i l'adquisició d'aprenentatges per part dels estudiants.

Per una altra banda, l'estudi de les relacions entre informació i coneixement així com, l'estudi de la competència digital ens ha permès concretar el perfil TIC del docent i de l'alumne actual.

En els plantejaments didàctics globalitzats dels tres centres educatius, hem trobat clares connexions amb els referents teòrics analitzats. Els sis projectes descrits il.lustren com la tecnologia està totalment integrada en els dissenys pedagògics d'èxit.

\footnotetext{
a Universitat Rovira i Virgili
} 